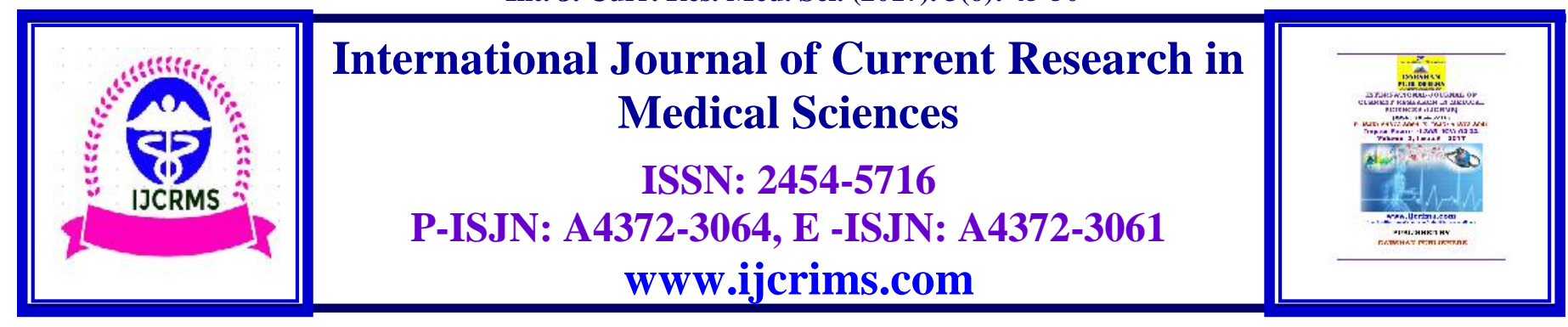

Review Article

Volume 3, Issue 6 -2017

DOI: http://dx.doi.org/10.22192/ijcrms.2017.03.06.007

\title{
Literature Review on Siddha Medicines Available for the Management of PCOS - A Review
}

\author{
S. Mohamed Ajmal ${ }^{1}$, Raja Rajeswari. $\mathrm{A}^{2}$ \\ ${ }^{1}$ UG Scholar, Sivaraj Siddha Medical College, Salem. \\ ${ }^{2}$ Department of Sool and Magalir Maruthuvam, Sivaraj Siddha Medical College, Salem. \\ *Corresponding author: mohamedajmal955@gmail.com
}

\begin{abstract}
Polycystic ovarian syndrome (PCOS) is known by the name of Stein-leventhal syndrome also called as hyper androgenic anovulation. Incidence of this disease is increasing day by day due to change in life style pattern, stress, pollution \& many more causes in growing young women during her reproductive age. It is one of the most common cause for infertility in women. Poly Cystic Ovarian Syndrome is a condition that has cysts on the ovaries that prevent the ovaries from performing normally. This is one of the major burning problem in front of society. The aim of this review is to discuss the available therapeutics in Siddha for the management of PCOS and its associated conditions
\end{abstract}

Keywords: Anovulation, Stein-leventhal syndrome, Poly Cystic Ovarian Syndrome.

\section{Introduction}

Siddha system of medicine is the traditional medicine of our ancestors which has its foundations from superior wisdom of Siddhars. Siddhars are those who lived and maintained the body as they desired best. They are responsible for the tamil medicine of the present day and also for many other sciences of public utility. Siddha system spread worldwide because of its significant beneficial effect with insignificant side effect. The disease which were challenging to the medical world were often treated well by our system. One of such disease is Garpavaayu. As per the text of Pararasasekeram, Garparogam is classified into 9 types. Garpavaayu is one among them. The symptoms of Garpavaayu are abdominal discomfort, dysmenorrhoea, low back ache, constipation, amenorrhoea, and heaviness of thigh. It may be correlated with Poly Cystic Ovarian Syndrome of modern science of medicine. The classical Siddha literature Pararasasekaram cites that any imbalance in three humours may inhibit the release of ovum from the ovaries. This may be related to the infertility due to ovulatory factors ${ }^{(1)}$.

Polycystic ovarian syndrome (PCOS) is one of the most common reproductive health problems of women. It was considered as a problem of anovulation and infertility, which is characterised by irregular menstruation, obesity, insulin resistance, hirsutism, acne, alopecia and recurrent miscarriage $^{(2) .}$ The incidence appears to increase 
due to change in life style and stress. Its prevalence in India ranges from 2.2 to $26 \%$ with the age $18-45$ years ${ }^{(3)}$. It is one of the most poorly defined endocrinological conditions with a complex pathophysiology that has produced considerable scientific debate.

Women with PCOS are at increased risk of reproductive problems including infertility, endometrial CA, late menopause, and also metabolic disturbances including insulin resistance, type II diabetes mellitus, cardiovascular disease, dyslipidemia ${ }^{(4)}$. The aim of this review is to discuss the available therapeutics in siddha for the management of PCOS and its associated conditions.

Reviewing the modern science literature regarding PCOS and Siddha literature nearer to symptoms and pathogenesis of PCOS and proper line of Siddha treatment for PCOS and its associated conditions.

\section{Modern concept}

PCOS is the complex multisystem disorder causing dysfunctional of three inter related axes i.e. metabolic, steroidogenic and reproductive. Root causes of PCOS is hyperinsulinemia, it is result of following conditions.

1. Excess weight and obesity ${ }^{(5)}$ : It is linked to insulin resistance, an imbalance of glucose and insulin levels hyperinsulinemia in the body.

2. Teenage: There is increase of sex steroid and growth hormone during puberty which stimulates the production of insulin-like growth factor-1, in response to develops hyperinsulinemia ${ }^{(6)}$. May be some teenagers fail to normalize the hyperinsulinemia whom are more prone to develop PCOS.

PCOS also increases the risk of developing the cluster of cardiovascular risk factors called metabolic syndrome. PCOS sufferers with metabolic syndrome are also at greater risk of developing gestational diabetes during pregnancy as well as health hazard in letter age like type II diabetes, hypertension, coronary heart disease and endometrial, liver, breast and colon cancer.

Possible effect of hyperinsulinemia on the HPO axis

1. Effect of hyperinsulinemia on the hypothamus and pituitary ${ }^{(7):}$ Hyperinsulinemia $\rightarrow \uparrow \mathrm{GnRH}$ from hypothalamus $\rightarrow \uparrow \mathrm{LH}$ and $\downarrow \mathrm{FSH}$ from the pituitary $\rightarrow$ chronic anovulation.

\section{Effect of hyperinsulinemia on the ovary and} liver $^{(4):}$ Increase insulin level creates estrogenic state in the body through the disturbance of ovarian and liver functions as,

Hyperinsulinemia $\rightarrow$ 个the testosterone and androstenedione in the ovary and the SHBG (Steroidal Hormone Binding Globulin) in the liver $\rightarrow \uparrow$ the bio-availability of estrogen in the female body. It is leading cause of infertility, recurrent pregnancy loss, menstrual disturbances ranging like amenorrhoea to dysfunctional uterine bleeding, hirsutism, alopecia and acne.

Investigation of PCOS are multiple cystic ovary by USG, LH $\geq 10 \mathrm{mIU} / \mathrm{ml}$ in early follicular phase or the ratio LH: $\mathrm{FSH}$ is $>2$, Raised serum testosterone and insulin level.

\section{Management of PCOS can be categorized in two aspects}

1. Curative for infertility and menstrual disorders. 2. Preventive for hypertension and type II diabetes and endometrial cancer by treating of PCOS.

\section{Siddha concept ${ }^{(8)}$}

Siddha deals PCOS as a Kapham disorder of (tridosha) mukkutram. Siddha text demonstrates all the 4,448 diseases are due to "Aamam" the indigested food material. Any food substances which doesnot attained the final state of nutrition remained as a pathogenic substance called "Mandham" or "Aamam". 


\section{Agni (the prince concept of transformation)}

The metabolic events over the GI level, liver level and tissues level are governed by Agni and Agni only. The narrow sense of Agni, we look over in digestive events. The wider sense of Agni, we have to view in metabolic events. Basically Agni should be understand before enter into the concept of PCOS.

\section{PCOS -Pancahbhoodas view}

Ovaries are classified under Aagaya bhudam, they are structurally Aagayam and functions carried by the ovaries are Thee (fire) for ovary function, both of these bhudam should be intact.

The ovum is maturing with the help of Aagaym and Vaayu. One single follicle has to mature with Aagayam and Vaayu bhudam along with Thee which helps in the rupture of the follicle. With Aagayam, Vaayu and Thee, the ovum matures and travel towards Mann (uterus) where they get implanted, if conception or shed after growth in certain period (mensturation). In PCOS, the problem lies in Aagayam, the deficit of Aagayam produces and increases vayu, results in number of immature follicles, the loss of Aagayam is compensaed by Neer budham which we called as cyst. Due to increased Mann (stromal tissues) follicle doesnot grow further.

\section{Menstruation-physiology of Siddha}

Vaatham is responsible for the maturation and movement of follicle, rupture and release of ovum in ovarian cycle. The Pitham is the energy of transformation which expresses the nature of hormones assists in the rupture of the follicle. Kapham the heavy and cool qualities nourishes the tissues of the uterus (endometrium) and entire reproductive system.

\section{Pcos-mukkutram approach}

In PCOS, Kapham is the kutram deranged clinically seen. Increased Kapham obstructs Abanan and develops amenorrhea. In thondam, we speak as Kaphavaatham disorder due to deranged Pitham.
Another school of thought says Vaatham and Kapham are responsible for normal menstrual cycle. Due to imbalance channels gets blocked resulting in amenorrhoe. A diminished Vaatham in its region causes amenorrhoea, dysmenorrhoea, constipation. Spread of Vaatham in Kapham and Pitham region cause hirsutism, acanthosis nigricans. Increase of Kapham in Pitham and Vaatham region cause obesity, lethargy. Pitham if boosted will regulate menstruation and will check out the other symptoms like hirsutism, acanthosis, weight gain and lethargy.

\section{Pcos-clinical view}

Clinically two categories such as obese PCOS and lean PCOS. Kaphavaatham disorder of which Mann and Vaayu is the role played. PCOS is due to Kapham blocking Vaatham and Pitham, hence the movement and transformation is suppressed.

\section{Overall goal of treatment of PCOS according to Siddha}

1. To reduce the Kapham(mann)

2. To reduce the Vaatham

3. To balance the Pitham

4. To stabilize the Agni inside ovaries.

\section{Siddha treatment for PCOS}

The (Table 1,2,3,4,5)given table below deals with the various Siddha formulations that are used for the management of PCOS and its associated conditions. 
Int. J. Curr. Res. Med. Sci. (2017). 3(6): 45-50

Table-1. Siddha formulations for $\operatorname{PCOS}^{(9,10,11)}$

\begin{tabular}{|c|c|c|c|c|}
\hline S.no & $\begin{array}{l}\text { Name of the } \\
\text { formulation }\end{array}$ & $\begin{array}{l}\text { Nature of the } \\
\text { formulation }\end{array}$ & Indications & Dosage \\
\hline 1. & $\begin{array}{l}\text { Chitiramoola } \\
\text { Kuligai }\end{array}$ & Herbomineral & $\begin{array}{l}\text { Yoni putru, Soolai } \\
\text { noigal }\end{array}$ & One black paper size \\
\hline 2. & Kumari Lehgyam & Herbal & Madhavidai pinigal & 5-10g twice a day \\
\hline 3. & $\begin{array}{l}\text { Arumuga } \\
\text { Chenduram }\end{array}$ & Herbomineral & Vedisoolai & $\begin{array}{l}200 \text { mg with } \\
\text { Thirikadugu } \\
\text { chooranam } \\
\text { Adjuvant-Honey }\end{array}$ \\
\hline 4. & $\begin{array}{l}\text { Agasthiyar } \\
\text { Kuzhambu }\end{array}$ & Herbomineral & Soodhaga vaayu & $\begin{array}{l}\text { One kundrimani size } \\
(130 \mathrm{mg}) \text { should be } \\
\text { taken along with } \\
\text { Naaval pattai saaru } \\
\text { and Seeraga podi for } \\
3 \text { days }\end{array}$ \\
\hline 5. & $\begin{array}{l}\text { Rasagandhi } \\
\text { Mezhugu }\end{array}$ & Herbomineral & $\begin{array}{l}\text { Yoni silandhi, Yoni } \\
\text { putru }\end{array}$ & $500 \mathrm{mg}$ twice a day \\
\hline 6. & Navauppu Mezhugu & Herbomineral & $\begin{array}{l}\text { Soolai, Soodhaga } \\
\text { vaayu }\end{array}$ & One black pepper size \\
\hline 7. & Nandhi Mezhugu & Herbomineral & Garba azhivunoi & $\begin{array}{l}500 \mathrm{mg} \text { once or twice } \\
\text { a day } \\
\text { Adjuvant-Palm } \\
\text { jaggery }\end{array}$ \\
\hline 8. & Siddhathi Ennai & Herbomineral & Garba soolai & $\begin{array}{l}\text { 3-5 drops with sombu } \\
\text { kudineer }\end{array}$ \\
\hline 9. & Senkottai Nei & Herbal & Vaatha noi & 5-10 ml twice a day \\
\hline 10. & Kumatty chooranam & Herbal & Gunmam & $4.1 \mathrm{~g}$ once a day \\
\hline 11. & $\begin{array}{l}\text { Vaankumari } \\
\text { Lehgyam }\end{array}$ & Herbomineral & Sarvaroga nivarani & $\begin{array}{l}2-4 \text { g with water } \\
\text { twice a day }\end{array}$ \\
\hline 12. & $\begin{array}{l}\text { Nilakadambu } \\
\text { Chooranam }\end{array}$ & Herbal & $\begin{array}{ll}\text { Soothaga } & \text { vali, } \\
\text { Perumbadu } & \end{array}$ & $2 \mathrm{~g}$ with milk \\
\hline 13. & $\begin{array}{l}\text { Gunma } \quad \text { Kudori } \\
\text { Mezhugu }\end{array}$ & Herbal & Soodhaga vaayu & One sundai alavu \\
\hline 14. & Pattu Karuppu & Herbomineral & Soodhaga sanni & 1-2 arisi alavu \\
\hline
\end{tabular}

Table-2. PCOS- Amenorrhoea ${ }^{(12)}$

\begin{tabular}{|l|l|l|}
\hline S.no & Name of the formulation & Dosage \\
\hline 1. & $\begin{array}{l}\text { Chukku thylam or } \\
\text { Aswagandha balalakshaddi thylam }\end{array}$ & Oil bath \\
\hline 2. & Agasthiyar kuzhambu & $130 \mathrm{mg}$ with Karunochil juice for 3 days \\
\hline 3. & Malai vembadhi thylam & $3-5 \mathrm{ml}$ with Neeraharam from 1 to 15 days \\
\hline 4. & Karunjeeraha chooranam & $2 \mathrm{~g}$ twice a day with water \\
\hline 5. & Thirikadugu chooranam & $1 \mathrm{gm}+$ Pattukaruppu $50-100 \mathrm{mg}$ for 10 days \\
\hline 6. & Gunmauppu chooranam & $250 \mathrm{mg}$ thrice a day with Neeraharam \\
\hline
\end{tabular}


Int. J. Curr. Res. Med. Sci. (2017). 3(6): 45-50

Table-3. PCOS- Menorrhagia ${ }^{(12)}$

\begin{tabular}{|l|l|l|}
\hline S.no & Name of the formulation & Dosage \\
\hline 1. & $\begin{array}{l}\text { Chukku thylam or } \\
\text { Aswagandha balalakshaddi thylam }\end{array}$ & Oil bath \\
\hline 2. & Asokapattai Chooranam & $5 \mathrm{~g}$ twice a day with honey \\
\hline 3. & Ayachendooram & $100 \mathrm{~g}$ twice a day with honey \\
\hline 4. & Padigapoongavi chendooram & $300 \mathrm{mg}$ twice a day with honey \\
\hline & Neeradimuthu vallathy cap & 1 twice a day with palm jiggery \\
\hline 5. & Kombarakku chooranam & $2 \mathrm{~g}$ twice a day till get bleeding arrest \\
\hline
\end{tabular}

Table-4. PCOS- Infertility ${ }^{(12)}$

\begin{tabular}{|l|l|l|}
\hline S.no & Name of the formulation & Dosage \\
\hline 1. & Aswagandha balalakshaddi thylam & Oil bath \\
\hline 2. & Agasthiyar kuzhambu & $130 \mathrm{mg}$ with Karunochil juice for 3 days \\
\hline 3. & Karpooradhi Chooranam & $\begin{array}{l}20 \mathrm{~g}+\text { Poornachandrodayam chendooram } 1 \mathrm{~g} \\
\text { twice a day with honey }\end{array}$ \\
\hline 4. & Nilakadambbu Chooranam & $1 \mathrm{~g}$ twice a day with water \\
\hline 5. & Naga parpam & $100 \mathrm{mg}$ twice a day with milk \\
\hline 6. & Karisalai karpam tablet & 2 twice a day with water \\
\hline
\end{tabular}

Table-5. Drugs for obese and lean individuals ${ }^{(8)}$

\begin{tabular}{|l|l|l|l|}
\hline S.no & For obese individuals & S.no & For lean individuals \\
\hline 1. & Kazharchi Cooranam & 1. & Pithasura Kudineer \\
\hline 2. & Panjadeepakini Leghyam & 2. & Kumari Leghyam \\
\hline 3. & Kaphasura Kudineer Chooranam & 3. & Satavari Leghyam \\
\hline 4. & Gunmauppu Chooranam & 4. & Venpoosani Nei \\
\hline 5. & Inji Chooranam & 5. & Pavala Parpam \\
\hline 6. & Amukkara Chooranam & 6. & Annapavala Chendooram \\
\hline 7. & Annabedhhi Chendooram & 7. & Satavari Nei \\
\hline 8. & Thalisadhi Chooranam & 8. & Silasathu Parpam \\
\hline 9. & Naga Parpam & 9. & Vaathasura Kudineer \\
\hline 10. & Karisalai Karpa Chooranam & 10. & Thirakshaadhi Chooranam \\
\hline
\end{tabular}

\section{Conclusion}

The above mentioned formulations are effectively used for the management of PCOS and its related complications. Besides, many other plants and formulations posses hypoglycemic activity (corrects the insulin resistance) and hypolipidemic activity (reduces obesity) may also be considered to be brought into the treatment regimen of PCOS. Most of the above mentioned therapeutics are employed based on contemporary practice. However, these are yet to be scientifically proved by clinical trial so that it may be adopted by the conventional medicine and thus helpful for the suffering women. 


\section{References}

1. Pararasasekeram Garpa roga nithanam, $1^{\text {st }}$ edition. Pg no 1, 2.

2. Howkins and Borne Shaws, Text book of gynaecology, $14^{\text {th }}$ edition, p.no 331

3. Nidhi $R$, Padmalatha $V$, Nagarathna $R$, Amritanshu R, Prevalence of polycystic ovarian syndrome in Indian adolescents, 2011, p.no 223-227.

4. Robert W Shaw, David luesley, Ash monga, Text book of gynaecology, $4^{\text {th }}$ edition, p.no 256.

5. Dutta D.C, Text book of Gynecology, $7^{\text {th }}$ edition, 2008, p.no 443.

6. Leon Speroff, Marc A. Fritz, Clinical Gynecologic Endocrinology and Infertility, 2005, p.no 369
7. Rao Kamini, The infertility manual, Jaypee brothers, New Delhi, 2004, p.no 91.

8. Siddha approach clinical experience, Siddha treatment for PCOS hand book, National seminar for prevention and management of PCOS, 2017, pg.no 41.

9. The controller of publications, The Siddha Formulary of India, Volume $1,1^{\text {st }}$ edition, p.no 36,60,68,69,70,71,72,104,132,156.

10. SKM Anubhavamurai, $1998,1^{\text {st }}$ edition, pg.no 38.

11. Dr.Kuppusamy mudaliyar, Siddha Vaidhiya Thirattu, 2016, $6^{\text {th }}$ edition, pg.no $63,200,201$, 215.

12. Dr.Sharf Nisha, Polycystic Ovarian Disease, Siddha treatment for PCOS hand book, National seminar for prevention and management of PCOS, 2017, pg.no 21, 22.

\begin{tabular}{|c|l|}
\hline \multicolumn{2}{|c|}{ Access this Article in Online } \\
\hline Quick & Website: \\
& www.ijcrims.com \\
\cline { 2 - 2 } & $\begin{array}{l}\text { Subject: } \\
\text { Siddha Medicine }\end{array}$ \\
\hline
\end{tabular}

How to cite this article:

S. Mohamed Ajmal, Raja Rajeswari.A. (2017). Literature Review on Siddha Medicines Available for the Management of PCOS - A Review. Int. J. Curr. Res. Med. Sci. 3(6): 45-50.

DOI: http://dx.doi.org/10.22192/ijcrms.2017.03.06.007 